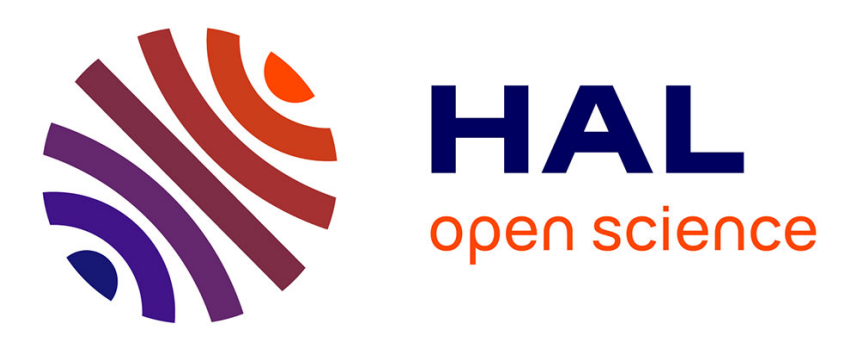

\title{
Venture Capital, the Regions and Public Policy: The United Kingdom Since the Post-2000 Technology Crash
}

Colin Mason, Yannis Pierrakis

\section{To cite this version:}

Colin Mason, Yannis Pierrakis. Venture Capital, the Regions and Public Policy: The United Kingdom Since the Post-2000 Technology Crash. Regional Studies, 2011, pp.1. 10.1080/00343404.2011.588203 . hal-00725358

\section{HAL Id: hal-00725358 \\ https://hal.science/hal-00725358}

Submitted on 25 Aug 2012

HAL is a multi-disciplinary open access archive for the deposit and dissemination of scientific research documents, whether they are published or not. The documents may come from teaching and research institutions in France or abroad, or from public or private research centers.
L'archive ouverte pluridisciplinaire HAL, est destinée au dépôt et à la diffusion de documents scientifiques de niveau recherche, publiés ou non, émanant des établissements d'enseignement et de recherche français ou étrangers, des laboratoires publics ou privés. 


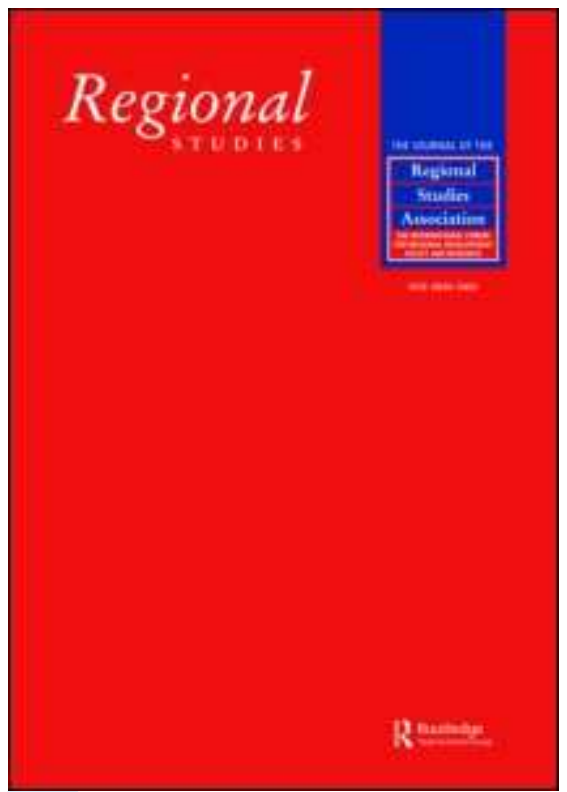

\section{Venture Capital, the Regions and Public Policy: The United Kingdom Since the Post-2000 Technology Crash}

\begin{tabular}{|r|l|}
\hline Journal: & Regional Studies \\
\hline Manuscript ID: & CRES-2009-0266.R3 \\
\hline Manuscript Type: & Policy Debates \\
\hline JEL codes: & $\begin{array}{l}\text { G2 - Financial Institutions and Services < G - Financial Economics, } \\
\text { R5 - Regional Government Analysis < R - Urban, Rural, and } \\
\text { Government|Intergovernmental Relations < H - Public Economics, } \\
\text { R1 - General Regional Economics < R - Urban, Rural, and Regional } \\
\text { Economics }\end{array}$ \\
\hline Keywords: & $\begin{array}{l}\text { venture capital, regions, regional policy, SMEs, entrepreneurship, } \\
\text { co-investment schemes }\end{array}$ \\
\hline
\end{tabular}

\section{SCHOLARONE" Manuscripts}




\title{
VENTURE CAPITAL, THE REGIONS AND PUBLIC POLICY: THE UNITED KINGDOM SINCE THE POST-2000 TECHNOLOGY CRASH
}

\author{
Colin Mason* and Yannis Pierrakis** \\ * Hunter Centre for Entrepreneurship, University of Strathclyde, Glasgow G1 1XH, Scotland, \\ UK. E-mail: colin.mason@strath.ac.uk \\ ** National Endowment for Science, Technology and the Arts (NESTA), 1 Plough Place, \\ London, EC4A 1DE, UK. E-mail: Yannis.Pierrakis@ @esta.org.uk
}

(Received August 2009: in revised form April 2011) 


\begin{abstract}
The geography of venture capital in the UK has been shaped since 2000 by a significant increase in public sector venture capital funds. Venture capital investments are now less concentrated in the South East. However, investment activity in the Midlands and North is dominated by the public sector. Deal sizes in these regions are small. Venture capital, measured by the total amount invested, remains over-concentrated in London and the South-East where private sector investors continue to dominate. The paper concludes by questioning whether this increased dependence of Northern regions on public sector venture capital matters.
\end{abstract}

Key words: venture capital, regions, regional policy, SMEs

JEL: G2, G3, R1, R5

\title{
1. INTRODUCTION
}

Venture capital - which we define as independently managed, dedicated pools of capital that focus on equity and equity-linked investments in privately-held, high growth companies (Lerner, 2009) - plays a central role in the emergence of new industries by funding and supporting innovative companies which come to dominate these industries ${ }^{1}$ (Gompers and Lerner, 2001, ch. 4). Venture capital investment speeds the development of companies, enabling them to transform ideas quickly into marketable products and become industry leaders through first mover advantages (Zhang, 2007). Venture capital-backed companies aim at more radical innovations, are significantly faster in introducing their products to the market and pursue more aggressive market strategies than other start-ups (Hellmann and Puri, 2000, 2002). This, in turn, means they are younger when they achieve an IPO compared with companies that were not venture capital 
backed, and they sustain their success for much longer after their IPO (Gompers and Lerner, 2001). Peneder (2010) finds that venture capital-backed firms grow significantly faster than other firms. Of course, venture capital firms are highly selective in the types of firms that they will invest in. Specifically, they seek to invest in businesses that have the potential to generate a large return on their investments in a five to seven year time frame through an initial public offering (IPO) or sale of their investee business to a corporate buyer. VCs therefore invest in management teams that are capable of rapidly building an enterprise, and in businesses that have a durable competitive advantage, where rapid expansion has significant payoffs, and which operate in markets that already have sizeable sales in conjunction with a large number of potential users who have not yet become customers (Bhidé, 2007). Peneder (2010) further demonstrates that the positive impact of venture capital investment on growth remains after controlling for the selection effect.

However, the availability of venture capital is restricted in three key respects. First, because of the fixed costs involved in the investment process it is uneconomic for venture capital funds to make small investments. Indeed, the increasing size of funds under management has driven up the typical size of investment (Murray, 1999; Dimov and Murray, 2008). This, in turn, has led to a shift away from investing in start-ups in favour of businesses in growth mode which have greater capital needs. As a consequence, business angels have become a more significant source of capital for new and young businesses (Mason, 2006; Mason and Harrison, 2010). Second, venture capital firms tend to concentrate their investments in just a few industries, reflecting their tendency to 'herding behaviour' which, in some cases, becomes myopia (Sahlman and Stevenson, 1986; Valliere and Peterson, 2004). Third, and the focus of this paper, research in 
various countries shows venture capital investments are geographically clustered, typically in the most technologically advanced regions (e.g. Florida and Kenney, 1988; Florida and Smith, 1991; Zook, 2002; Mason, 1987; Mason and Harrison, 1991; 2002; Martin et al, 2002; 2005; Chen et al, 2010). This is attributed, on the one hand, to the spatial clustering of venture capital firms and the localised nature of the investment process, and on the other hand, to the availability of suitable investment opportunities (Mason, 2007b).

Reflecting the importance of venture capital in both innovation policy, facilitating the commercialisation of the science base, and entrepreneurship policy, facilitating the emergence of high growth businesses, national and state/regional governments have responded to these gaps in the availability of venture capital with initiatives to increase its supply. In many cases these schemes have an explicit geographical focus on under-supplied regions and localities. The aim of this paper, which follows in the tradition of previous studies of the geography of venture capital investing (see earlier citations), is to show how a combination of this increased government intervention in the UK to address perceived market failures in the availability of venture capital and a decline in private sector investing in the aftermath of the dot-com induced technology crash, has re-shaped the UK's geography of venture capital in significant ways. The paper's contribution arises from its use of a data source not previously employed in studies of the geography of venture capital which makes it possible, for the first time, to distinguish between private and public sector investments across the UK regions.

Our analysis shows that since 2000 the supply of venture capital across the UK regions has in some important respects become less unequal. This is largely an outcome of the increase in the 
supply of public sector venture capital, with the venture capital markets in the Midlands and North of England, along with Wales, Scotland and Northern Ireland, now dominated by public sector venture capital. However, given the emerging criticisms of the effectiveness and impact of public sector venture capital (Murray, 2007; Lerner, 2009; Nightingale et al, 2009) it is legitimate to question whether such investment is able to promote entrepreneur-led economic development in the regions. We raise this debate in the concluding section of the paper.

\section{VENTURE CAPITAL AND GOVERNMENT POLICY IN THE UK}

The UK has a long history of government intervention to fill gaps in the availability of finance to SMEs, dating back to the formation of Industrial and Commercial Finance Corporation (ICFC), the forerunner to $3 \mathrm{i} \mathrm{plc}$, the major private equity firm. Other significant, long-established policy interventions that continue to operate are the Enterprise Investment Scheme (EIS) and Venture Capital Trusts (VCTs) which offer tax incentives to private individuals who invest either directly or via managed funds in small unquoted companies.

The policy regime that operated during the first decade of the $21^{\text {st }}$ century was a product of the New Labour Government elected in 1997. Its 1998 Competitiveness White Paper (Department of Trade and Industry, 1998) had a strong focus on increasing the supply of venture capital throughout the UK. Indeed, one of the key objectives was to ensure that each of the regions had access to local smaller scale equity investors. These policy interventions were based on the belief that there was a "market failure in the provision of finance in amounts below $£ 500,000$ for SMEs with growth aspirations" (Department of Trade and Industry, 1999). ${ }^{2}$ This justification for intervention on the basis of filling gaps in supply in order to remove constraints on the ability of 
businesses to grow - which is seen as a serious impediment to the UK's economic success - was maintained in the Labour Government's final policy paper New Industry, New Jobs (HM Government, 2009: 10).

The intervention took the following form (Table 1).

- Regional Enterprise Funds: autonomous regional venture capital funds were established in each English region. These funds were privately managed and commercially focused but cofunded by government, the European Investment Fund and institutional investors (mainly banks). Institutional investors were encouraged to invest by means of a structure that capped the returns to government and subordinated their losses (i.e. government bore the first loss). Investments were initially limited to a maximum of $£ 500,000$ but subsequently raised to $£ 660,000$.

- UK High Tech Fund: a national venture capital scheme to support early stage, high technology businesses, operating as a "Fund of Funds" to invest in privately owned and managed venture capital funds which support early stage, high technology businesses.

- Early Growth Funds: a budget to provide funding for innovative proposals to develop new initiatives to increase the availability of small amounts of risk capital for start-ups and small businesses with growth potential. These comprised a mixture of regional and national funds based on co-investing with business angels.

With the exception of the UK High Tech Fund none of the funds were targeted at specific sectors. 
In addition, eight of the nine Regional Development Agencies in England also established their own regional venture capital funds (the exception is the East of England), in some cases with funding from the Early Growth Funds. The upper limit of investments by these funds ranged from $£ 50,000$ to $£ 250,000$. The devolved nations (Scotland, Wales and Northern Ireland) also have their own venture capital schemes. For example, the Scottish Co-Investment Scheme, launched in 2003 with financial support from ERDB, invests alongside approved investment partners (mainly angel groups). Any business that an investment partner has invested in that meets the scheme's eligibility rules can access matched funding up to a maximum total investment of $£ 1 \mathrm{~m}$.

\section{TABLE 1 ABOUT HERE: \\ Publicly backed venture capital funds}

The design of these funds reflected a fundamental shift of approach to more indirect forms of intervention alongside private investors. Previous approaches involving the creation of publicly funded and managed venture capital funds had raised concerns about the competence of governments to undertake venture capital investments (Murray, 2007) and market distortion through the 'crowding out' of private investors (Leleux and Surlemont, 2003). These new funds were hybrids, with structures where government and private investors work in together as coinvestors (Murray, 2007). Three approaches are in evidence. The Regional Enterprise Funds involved government co-investing alongside private institutional investors in funds which were managed by private sector professionals. Government attracted private investors as co-investors in the fund by increasing their 'upside' returns, contributing to the operating costs of the fund, or underwriting some or all of the losses of the private investors (Murray, 2007). The UK High Tech Fund was a fund-of-funds which invested government money in privately owned and 
managed venture capital funds. The Early Growth Funds were established as co-investment funds, investing alongside private investors (both business angels and private venture capital funds).

The launch of the scheme was delayed because of European Union 'state aid' concerns and so only came on-stream in 2002-2003. However, as the paper will show, they quickly became important players in the supply of early stage venture capital, changing the investment landscape. The Regional Venture Capital Funds came to an end in 2008. The UK High Technology Fund has also stopped making investments. However, new funds created under the auspices of the EU JEREMIE scheme are due to come on stream in several regions ${ }^{3}$. The other funds are still operational (SWQ Consulting, 2009). Using the data sources described in the next section, the aim of the paper is to examine how this growth in public sector venture capital has changed the geography of venture capital investment in the UK since 2000.

\section{DATA SOURCES}

The paper draws on two data sources. The first is the annual reports on investment activity published by the British Venture Capital Association (BVCA). This is based on a survey undertaken by PriceWaterhouseCoopers - of the Association's members which comprise the vast majority of private equity and venture capital firms. It achieves a very high response rate, often $100 \%$. Previous studies of the geography of venture capital in the UK have used this source (e.g. Mason and Harrison, 1991, 2002). The main limitation is that the level of disaggregation is quite limited, especially at the regional scale. In order to probe beyond the statistics that are reported by the BVCA we utilise Library House data (now absorbed into Dow Jones Venture Source) 
which reports individual investments along with various additional information on the investor and business which enabled customised tables to be generated. ${ }^{4}$ It is important to note that Library House's coverage of investment activity is narrower than that of the BVCA, and in particular does not extend to private equity investments. In addition, its database is built up from reported investments and so does not capture all the investments that BVCA reports in its annual investments activity reports ${ }^{5}$. In addition, the amount of information that is provided about each investment in Library House's database is limited, which restricts the amount of disaggregation possible. In particular, only total amounts invested are provided: amounts invested by individual investors are not given. On the other hand, it does capture some investments, notably those by angel groups and high net worth individuals making large investments, which are not included in BVCA investment statistics. ${ }^{6}$

From the Library House database it is possible to identify three types of investments:

- Those involving one or more private sector investors. This category primarily captures venture capital firms, but also includes and separately identifies investments by banks and other debt providers, charities, trusts and foundations and companies although not on a consistent basis. More significantly it also identifies investments made by some types of business angels, notably investor networks (e.g. angel syndicates), family offices and named and un-named high net worth individuals. On account of their size these investments are much more visible than those of typical business angels. However, a key limitation of the data is that investments by business angels (angel groups and some named individuals) are only identified where they have co-invested with either private or public sector funds. 
- Those involving one or more publicly backed funds (e.g. Regional Venture Capital Funds). These are funds which have received some or all of their capital from the public sector, including central government departments, regional development agencies and the European Union (e.g. ERDF). They are normally managed by independent fund managers. However, the database does not differentiate between co-investment funds and other public sector funds. So, for example, investments made by the Scottish CoInvestment Fund, Scottish Seed Fund, Scottish Venture Fund and Business Growth Fund are not separately identified but simply classified as 'Scottish Enterprise'. Nor does it identify those funds that attracted investment from the UK High Tech Fund.

- Deals - which we term co-investments - in which one or more private sector investors has invested alongside one or more public sector funds. Investments in this category include both ad hoc syndications between public sector funds and private investors and also investments involving Co-Investment Funds that have been established specifically to invest alongside private investors.

The Library House database does not identify investments made using the EIS and its coverage of investments by VCTs is very patchy and so are not considered in the following analysis

\section{VENTURE CAPITAL TRENDS IN THE UK SINCE 2000}

\subsection{Aggregate analysis}

The UK boasts the largest private equity market in Europe, accounting for one in every three investments. Statistics on investment activity collected by the British Venture Capital Association (BVCA) show that there was a collapse in venture capital investing in the immediate aftermath of the tech-crash (2001-3). However, the value of investments trebled between 2003 
and 2007 from $£ 4$ bn to nearly $£ 12$ bn but then fell by $28 \%$ from 2007 to 2008 as the financial crisis took hold (Figure 1). In contrast, the number of investments has remained fairly stable at around 1300 over the same period.

\title{
FIGURE 1 ABOUT HERE
}

Annual private equity and venture capital investment, 2001-8 (£m)

\begin{abstract}
These statistics include all forms of private equity and not just venture capital. Closer examination of the details behind these aggregate statistics indicates that this expansion in investment activity has been in 'private equity' rather than 'venture capital', propelled by a huge increase in funding for management buy-outs and buy-ins (MBOs and MBIs) (Figure 1). This has had the effect of driving up the average (mean) size of investment over the period, peaking at $£ 9 \mathrm{~m}$ in 2007 , more than twice its 2001 value, dropping back to $£ 6.7 \mathrm{~m}$ in 2008 . However, reflecting the highly skewed investment size distribution, more than three-quarters of all investments involve amounts of under $£ 2 \mathrm{~m}$ and around two-thirds are for under $£ 500,000$.
\end{abstract}

\section{TABLE 2 ABOUT HERE}

UK early stage investments 2000-2008

\begin{abstract}
The amount invested in early stage deals has recovered from the low point of the tech-crash in the early 2000s but has fallen since 2000 as a proportion of the total amount invested, apart from the anomalous year of 2006. The share of total investment activity accounted for by early stage investments has been less than 6\% in recent years (apart from 2006) (Table 2a). Numbers of
\end{abstract}


early stage investments on the other hand have modestly increased since 2001, albeit erratically, from $31 \%$ to $38 \%$ in 2007 , dropping back to $36 \%$ in 2008 (Table 2 b). The average size of early stage investments is now lower than at the start of the period (Table 2c).

\subsection{Types of investor - Total investments}

The additional dimension which the Library House database adds is evidence on changes in the supply of venture capital since the turn of the century. Specifically, it reveals that the public sector has become considerably more important as an investor in both absolute and relative terms. The number of deals involving public sector funds, either investing on their own or coinvesting with private investors (funds or individuals), has more than trebled between 2001 and 2007 , although fell by $18 \%$ in 2008 . This represents an increase in the share of investments involving the public sector from 19\% in 2001 to $44 \%$ in 2008 (Figure 2). Meanwhile, freestanding private sector investments - although increasing in numerical terms from 2002 until 2006 - have declined as a proportion of the total number of investments from $81 \%$ in 2001 to $56 \%$ in 2008 . These trends - two sides of the same coin - underline the growth and current scale of the public sector's involvement in one form or another in the supply of venture capital.

\section{FIGURE 2 ABOUT HERE:}

Proportion of investments by type of investor, 2000-2008

(Note: calculated on the basis of the number of investments)

The increasing significance of the public sector has risen on account of its growing use of coinvestment as an investment model. Co-investments accounted for $26 \%$ of investments in 2008 
compared with just 7\% of all investments in 2001 (Figure 2). Indeed, public-private coinvestments are now the dominant form of public sector venture capital investment, reaching a peak of $67 \%$ of all deals involving the public sector in 2007 compared with $37 \%$ in 2001, and since 2005 has exceeded the annual number of free-standing investments by public-sector funds (Figure 3a). One-third of private sector investments were co-investments with public sector funds in 2008 compared with just $8 \%$ in 2001 (Figure 3b), underlining that a significant proportion of private venture capital investment activity is now supported by the public sector.

\author{
FIGURE 3 ABOUT HERE \\ Co-investments as a proportion of deals \\ (Note: calculated on the basis of the number of investments) \\ FIGURE 4 ABOUT HERE \\ Distribution of deals sizes by type of investor, 2007
}

\begin{abstract}
These trends can be unpacked in two further respects. First, these various types of investors occupy different parts of the funding spectrum (Figure 4). Private investors (funds and individuals) had an average size of $£ 3.7 \mathrm{~m}$ in 2007 but a very wide size distribution, with $11 \%$ of deals below $£ 250,000$ but $45 \%$ above $£ 5 \mathrm{~m}$. The average public-private co-investment is smaller at $£ 1.5 \mathrm{~m}$, with $81 \%$ of investments at $£ 2 \mathrm{~m}$ and below. Deals involving only public sector funds were largely confined to $£ 500,000$ and under $(83 \%)$ ( $£ 378,000$ average size). Second, as noted above, the 'private sector' category comprises different types of investors, notably funds and private individuals, or business angels, investing individually or in groups. Separately identifying
\end{abstract}


business angels reveals that they have become more significant in both absolute and relative terms, their investments increasing more than threefold in numerical between 2001 and 2007 (Figure 5), but then dropped back by over one-quarter in 2008, and their share of private sector investment rising dramatically from $13 \%$ to over $40 \%$. Moreover, business angels and angel groups have become increasingly prominent as co-investment partners. Since 2005 they have been involved in more than $40 \%$ of all deals annually in which public sector funds participated. This reflects the maximum size of co-investment funds which is typically too small to interest venture capital funds. For example, at the time of its evaluation $71 \%$ of the partners in the Scottish Co-Investment Fund were business angel syndicates, and they had made $82 \%$ of the investments (Hayton et al, 2008).

\section{FIGURE 5 ABOUT HERE}

Number of investments with Business Angel involvement in the UK, 2001-2008

\subsection{Types of investor - Early stage investments}

The increased involvement of the public sector is even more apparent in the early stage venture capital market. Unlike BVCA investment statistics, which is classified by stage of investment, the Library House database categorises deals in terms of rounds. In the following discussion we therefore define an early stage investment as a round 1,2 or 3 investment that is below $£ 2 \mathrm{~m}$.

The involvement of the public sector in the supply of early stage venture capital has increased significantly to a situation in which it accounts for the majority of such investments by number (Figure 6). In 2001 public sector funds were involved in $36 \%$ of investments. By 2003, as the 
various funds established by the Labour Government came on stream, this had risen to $51 \%$ and by 2008 accounted for $68 \%$ of all investments.

A significant proportion of this increase in public sector investment activity has taken the form of co-investments which have risen from $10 \%$ of all early stage investments in 2001 to more than $30 \%$ since $2005 .^{7}$ The proportion of public sector investments which are co-investment deals has risen from $28 \%$ in 2001 to peak at $56 \%$ in 2007 , falling back to $45 \%$ in 2008 . Nevertheless private sector investors remain important, both as free-standing investors and co-investment partners, involved in more than $60 \%$ of all early-stage investments annually between 2001 and 2008 and in some years this proportion was in excess of $70 \%$. But what has happened is that an increasing proportion of early stage private sector investments have been co-investments with public sector funds, rising from $13 \%$ in 2001 to more than $45 \%$ since 2005 , while the proportion of independent private sector investments has fallen (to $32 \%$ of all investments in 2008).

\title{
Figure 6 ABOUT HERE:
}

Early stage investments by year and type of investor 2000-2008

(Note: calculated on the basis of the number of investments)

\begin{abstract}
A further significant development has been a change in the composition of the private sector category. Business angels have become increasingly significant as a source of early stage investment at the expense of private sector funds which have declined. Early-stage investments by business angels increased in numerical terms year-on-year between 2001 and 2007, but fellback back in 2008 . Their share of total private sector early stage investments has risen from $16 \%$
\end{abstract}


to $44 \%$ over the same period. Their share of total early stage investments increased from $12 \%$ in 2001 to $32 \%$ in 2007 , dropping to $28 \%$ in 2008.

\author{
4.4 Summary \\ Year-on-year trends in early stage venture capital investment since the post-2000 technology- \\ crash have been volatile. Amounts invested have increased but remain well short of their 2000 \\ peak. The number of investments has also risen, reflecting an increase in smaller investments of \\ under $£ 500,000$. The public sector has become proportionately more significant as an investor, \\ largely on account of the growth of public-private co-investment which is now the dominant way \\ in which the public intervenes in the venture capital market. Private sector investors remain \\ prominent in terms of the number of investments they make, but are now much more likely to \\ invest alongside the public sector in co-investment deals. The composition of early stage private \\ sector investors has also changed, with an increase in the significance of investments by private \\ individuals (including 'mega angels' investing alone, angel syndicates and other forms of \\ organised angel investing) and a decline in the significance of private sector venture capital \\ funds.
}

\title{
5. VENTURE CAPITAL TRENDS IN THE UK REGIONS
}

In the remainder of this paper we extend this analysis by shifting the focus from the national to the regional scale. It addresses two empirical questions: 
1. Does the geography of venture capital investments in the UK continue to be characterised by regional inequalities, as previous studies have indicated (Mason, 1987; 2007; Mason and Harrison, 1991b; 2002; Martin 1989; 1992; Martin et al, 2005)?

2. What has been the effect of the increased involvement of government in the supply of venture capital, as described in the previous section, on the geography of venture capital investments?

It is now well established that venture capital is not equally available in all parts of a country (Florida and Kenney, 1988; Florida and Smith, 1991; Green, 2004; Langeland, 2007; Martin et al, 2005; Mason and Harrison, 2002; Schwartz and Bar-El, 2007; Zook, 2002). Indeed, some types of government intervention have specifically focused on the 'regional equity gap' with initiatives designed to increase the supply of venture capital in specific regions and localities (Murray, 1998; Sunley et al, 2005). The uneven geography of venture capital investing is typically explained in terms of a combination of both supply and demand side factors. On the supply side, venture capital funds are clustered in a small number of cities. The concentration of venture capital investing in the regions and sub-regions in which venture capital firms are clustered occurs for two reasons. First, it reflects information on investment opportunities which, especially at the early stage, are highly localised. Second, investing locally is a means by which investors can reduce uncertainty and thereby minimise risk (Florida and Kenney, 1988; Sorensen and Stuart, 2001; Mason, 2007). Venture capital firms do make long distance investments, particularly as they mature (Cumming and Dai, 2010; De Clercq et al, 2001; Sorensen and Stuart, 2001), but this is normally in the context of syndicated investments with one or more other 
investors, and where one of the other investors - usually the lead investor - is local to the investee business (see Rosiello and Parris, 2009 for this feature in the UK biotechnology sector).

On the demand-side, the uneven geography of venture capital investments clearly reflects the uneven geography of entrepreneurial activity - and of growth potential firms in particular - and the clustering of technology-based firms. However, it also reflects spatial variations in awareness of venture capital and connections with investors which is a further consequence of the localisation of venture capital firms (Thompson, 1989). Knowledge and learning about venture capital will be high in the local business community in areas where venture capitalists are concentrated. Thus, both entrepreneurs and intermediaries, including accountants, bankers, lawyers and advisers, will have a greater understanding of the role and benefits of venture capital, what types of deals venture capitalists will consider investing in and the mechanics of negotiating and structuring investments, and intermediaries will have connections with venture capital firms to which they can refer clients. In areas which have few or no venture capital firms, in contrast, knowledge amongst entrepreneurs and the business support network will be weak and incomplete, intermediaries will lack connections with venture capital firms and, perhaps most significantly of all, will be less competent in advising their clients on what it takes to be 'investable'. The effect is to depress demand for venture capital (Martin et al. 2002).

\subsection{The regional distribution of venture capital investments: aggregate patterns}

BVCA statistics on investment activity are disaggregated by region and, as noted earlier, have been used in previous studies to examine the uneven geography of venture capital investments. There are various ways in which to measure the regional distribution of venture capital 
investments. Essentially there are three critical decisions. First, are venture capital investments measured in terms of number of investments or amount invested? Second, what types of venture capital investments are included? Investment statistics are disaggregated by stage of investment (start-up, other early, expansion and MBO/MBI). Third, should venture capital investment in each region be compared with that region's stock of companies, new firms, employment or population? Different conclusions may arise depending on the choices made. In what follows we present the regional distribution of venture capital in the form of location quotients which indicate each region's share of early stage (i.e. start-up and other early stage) venture capital investments (both number and amount) as a ratio of that region's share of national business activity (measured by the number of VAT-registered companies). A value of over one indicates that a region has more than its expected share of venture capital investments based on that region's share of the national business population whereas a value of less than one indicates that its share is less than expected. The analysis is presented for four separate time-periods which conform to aggregate investment trends. This also has the advantage of smoothing some of the year-on-year fluctuations in investment activity that are apparent at the regional scale.

TABLE 3 ABOUT HERE.

Distribution of early stage investments in the UK: number and region

TABLE 4 ABOUT HERE.

Distribution of early stage investments in the UK: amount invested and region

The regional distribution of early stage venture capital investments (Table 3) contrasts sharply with the regional distribution measured in terms of amounts invested (Table 4). For the period 
2005-7, regions with more than their expected share of venture capital investments by number included both the core regions of London, the South East and East of England and also several peripheral regions (North East, North West, Scotland). Regions with fewer than expected investments included Yorkshire and The Humber, the East Midlands, West Midlands, South West, Wales and Northern Ireland. In 2008, when the onset of the financial crisis resulted in a downturn in venture capital activity, London and the South East continued to have more than their expected share of venture capital investments, along with the North West, North East and also the East Midlands and Northern Ireland (Table 3).

However, a rather different picture emerges when the amount invested is considered. For both the 2005-7 and 2008 periods London and the South East each had more than their expected shares of early stage venture capital. The East of England, East Midlands and Yorkshire and The Humber also had more than their expected shares of investment activity in the $2005-7$ period, but in the latter two regions (which both had lower than expected shares of venture capital investments by number) this is an outcome of one atypical year and in the other years their location quotients were less than one. ${ }^{8}$ In 2008 the regional distribution of early stage venture capital by amount was dominated by London which attracted almost half of the total. Only London and the South East, along with the North East, attracted more than their expected shares of early stage venture capital by amount (Table 4).

Several regions have significantly more venture capital investments than expected but significantly less than expected shares of venture capital investment by value. This group comprises North West, Northern Ireland (both 2005-7 and 2008), the North East, Scotland (both 
2005-7 but not 2008) and the East Midlands (2008 only). The greater than expected number0 of venture capital investments in these regions clearly reflects a situation in which a large number of small scale investments have been made, a point that we return to later.

How stable is this geographical distribution of venture capital investment over time? Comparing the boom period of the late 1990s, the post 2000 downturn, the mid-decade recovery and the onset of the financial crisis (2008) reveals some contrasting trends for different regions:

- London and the South East have both consistently attracted more than their expected shares of early stage venture capital (both number and amount) across all four periods. They both continue to attract significantly more than their expected shares of venture capital, particularly in terms of the amounts invested (Mason and Harrison, 1991; 2002). However, whereas London's share of early stage venture capital in terms of amount invested has steadily increased over the past 10 years, from $22 \%$ in the boom years to $48 \%$ in 2008, the South East's share of both the number of investments and amount invested has fallen over the same period.

- East of England attracted more than its expected investment in the crash (2001-3) and recovery (2005-7) periods

- Scotland's position has deteriorated over the four periods in terms of its share of venture capital investment by value, having more than its expected investment in the boom of the late 1990s but less than its expected share in subsequent periods. This may be linked to the privatisation of Scottish Enterprise's venture capital division at the turn of the century (Hood 2000). However, until 2008 it consistently had more than its expected share of investments by number, reflecting the active role of Scottish Enterprise in the venture 
capital market and, in particular, the launch of its very successful co-investment scheme in 2003 (Haydon et al, 2008).

- The North East and North West have significantly improved their positions since 2001 in terms of having had more than their expected shares of venture capital investments, but only in terms of numbers of investments.

\subsection{The regional distribution of venture capital investments: types of investors}

Using Library House data we are able to decompose the types of venture capital investors in each region (Figure 7). Looking at the entire 2000-8 period, and only considering early stage investments (as defined earlier: round 1-3 investments under $£ 2 \mathrm{~m}$ ) it is apparent that there is a clear distinction between, on the one hand London, the South East and East of England and, on the other hand, the rest of the country in terms of the proportion of deals involving private and public sector investors. Looking at the period as a whole, deals exclusively involving private investors accounted for more than $70 \%$ of all investments in London, nearly two-thirds in the South East and 60\% in the East of England. In the South West and East Midlands the proportion of free-standing private sector investments was around 40\%, dropping to $32 \%$ in Scotland, around one-quarter in Yorkshire and The Humber, the North West, North East and Wales, and around $15 \%$ in West Midlands and Northern Ireland. This means that the public sector is involved in upwards of three-quarters of early stage venture capital investments in northern regions. Moreover, the proportion of deals involving the public sector has risen over time, reaching over $90 \%$ in several regions in 2008 (Figure 8). However, the form of public sector intervention varies. In Northern Ireland, Scotland and the North East co-investments between the public and private sector dominate, accounting for $64 \%, 52 \%$ and $42 \%$ respectively of all 
investments, whereas in the other regions with high proportions of public sector involvement notably the West Midlands, Wales, Yorkshire and The Humber, and the North West - freestanding public sector investments account for $50 \%$ or more of all investments.

FIGURE 7 ABOUT HERE.

Proportion of different types of investors in early stage deals in the UK regions 2000-2008

FIGURE 8 ABOUT HERE

Proportion of investments involving the public sector by year by region

FIGURE 9 ABOUT HERE:

Proportion of early stage deals involving business angels by region

The Library House data also provides some insight into regional variations in the relative significance of business angels. However, as noted earlier, the data are partial, with business angels only identified in deals where they have invested alongside venture capital funds. With this important caveat, business angels are most prominent in Scotland, accounting for over onethird of early stage investments, and the North East where they account for 30\%. They are least significant in Yorkshire and The Humber, North West, Northern Ireland and Wales (Figure 9). One way in which this regional pattern might be interpreted is in terms of the dominant form of public sector intervention (fund or co-investment), discussed in the previous paragraph. Based on the Scottish experience, a well-developed business angel market in which angels are members of angel syndicates is a pre-requisite for the successful operation of co-investment funds. The Scottish experience also suggest that the successful operation of a co-investment fund provides a further boost to the development of new angel syndicates (Hayton et al, 2008). In contrast, in 
regions where public sector venture capital funds dominate this could either be a response to the lack of organised angel groups or because such funds have crowded out business angels from the market.

\title{
6. CONCLUSION
}

The aim of this paper has been twofold: first, to update earlier evidence on the uneven geography of venture capital investing in the UK (Mason and Harrison, 2002) and second, to use deal specific information to reveal regional variations in the composition of venture capital investments. At the national scale there have been three significant changes in composition of early stage venture capital since 2000 . First, the public sector has become a much more significant source of early stage venture capital, following the various funds announced by the Labour Government in their 1997 Competitiveness White Paper coming on-stream in the early 2000s. Second, the form of intervention has shifted in its emphasis from public sector venture capital funds making direct investments in companies to co-investment funds which invest alongside private investors (business angels and private sector funds). Third, the composition of private sector investors has changed, with funds declining in significance and various types of business angels (high net worth individuals and angel groups) becoming more important.

\begin{abstract}
At the regional scale early stage venture capital, measured in terms of the amount invested, continues to be over-concentrated in the core regions of Greater London and South East England as it always has been (Mason, 1987; Martin, 1989; 1992; Mason and Harrison, 1991; 2002). However, several northern regions have more than their expected shares of early stage venture capital investments, measured by number of deals. This is largely a function of the activities of
\end{abstract}


public sector agencies, either investing on their own or in conjunction with private sector investors. Indeed, over the period as a whole the public sector has been involved in more than three-quarters of the early stage investments made in the Midlands and North, rising to more than $90 \%$ in some regions in 2008 . The proportion of free-standing private sector deals in these regions is correspondingly low. Moreover, the average size of these investments is small because of the upper limit on the size of investment that such funds can make in a single business (typically $£ 500,000$ ). As a consequence, the high level of investment activity does not translate into significant amounts being invested in these regions.

The upshot is that the UK now appears to have two early stage venture capital markets. In London, the South East and, to a lesser extent, the East of England, private sector investors dominate investment activity, investing for the most part on their own rather than with public sector co-investors. This contrasts with Northern regions where the early stage venture capital market is under-pinned by extensive public sector investment activity, much of which takes the form of co-investments with the private sector. In these regions free-standing investments by the private sector account for only a minority of investments and private sector investors are more likely to invest alongside the public sector in co-investment deals than to invest on their own. Moreover, this gap between London and the South East and the rest of the country in terms of the significance of public sector investments has widened since 2001, during periods of both declining and expanding venture capital investment activity.

This leads to the obvious concluding question: does it matter that the Northern regions of the UK are increasingly dependent on the public sector to supply venture capital? We argue that it does. 
Certainly, firms in receipt of finance from public sector funds report benefits, primarily in terms of enabling them to start or grow more quickly (NAO, 2009). However, Nightingale et al (2009: 20) report that "companies that are recipients of funding under one or more of the government's hybrid funding schemes examined do not yet exhibit significantly better performance" than similarly matched companies that have not received such funding. This conclusion is reinforced by evidence from the National Audit Office (2009) that the interim financial performance of both the UK High Tech Fund and Regional Venture Capital Funds were both negative. ${ }^{9}$ Many criticisms have attributed this to the poor design of the schemes (NAO, 2009: Pierrakis and Westlake, 2009), notably (i) the focus of such funds on specific geographical areas which restricts the supply of suitable investment opportunities, particularly in smaller regions, and (ii) the maximum size of investment as imposed by government (under $£ 500,000$ ) which is typically too small to meet the funding needs of high growth firms, and high-tech firms in particular (SQW Consulting, 2009), and are generally too small to have the capacity to make significant follow-on investments which, in turn, puts them at risk to punitive dilution. Others have argued that public sector venture capital funds may not be as 'smart' as their private sector counterparts in terms of adding value (Schafer and Schilder, 2009).

The growth of public sector venture capital in the UK has reduced the uneven regional geography of venture capital in the UK. However, this is only in terms of number of investments, not amounts invested. Thus, it remains questionable whether companies located outside of the Greater South East and which require significant amounts of finance can raise the amounts that they need. Second, the effectiveness of public sector venture capital in creating fast growth 
entrepreneurial businesses remains questionable. Hence, there continues to be a need to rethink how to develop venture capital in the UK regions.

Acknowledgement. We are grateful to the Editors and two anonymous referees for helping us to improve the structure and positioning of the paper.

\section{NOTES \\ SEE END OF TEXT}

\section{REFERENCES}

Bhidé, A. (2007) The Venturesome Economy. Princeton University Press, Princeton.

Chen, H., Gompers, P., Kovner, A. and Lerner, J. (2010) Buy local? The Geography of venture capital expansion Journal of Urban Economics, 67, 90-102.

Cumming, D. and Dai, N. (2010) Local bias in venture capital investments, Journal of Empirical Finance 17, 362-380.

De Clercq, D., Goulet, P. K., Kumpulainen, M. and Mäkelä, M. (2001) Portfolio investment strategies in the Finnish venture capital industry: a longitudinal study Venture Capital: an international journal of entrepreneurial finance, 3 (1), 41-62.

Department of Trade and Industry (1998) Our Competitive Future: Building the Knowledge Driven Economy. Cm 4176. The Stationary Office, London.

Department of Trade and Industry (1999) Addressing the SME Equity Gap: Support for Regional Venture Capital Funds. URN 99/876. Small and Medium Enterprise Policy Directorate, DTI, Sheffield 
Dimov, D. and Murray, G.C. 2008. Determinants of the incidence and scale of seed capital investments by venture capital firms Small Business Economics, 30: 127-152.

Florida, R. and Kenney, M. (1988) Venture capital, high technology and regional development, Regional Studies 22 (1), 33-48.

Florida, R. and Smith, D.F. jr (1991) Venture capital formation, investment, and regional industrialisation Annals of the Association of American Geographers, 83, 434-451.

Gompers, P. and Lerner, J. (2001) The Money of Invention: How Venture Capital Creates New Wealth. Boston: Harvard Business School Press.

Green, M. (2004) Venture capital in the United States 1995-2002, The Industrial Geographer 2 (1), 2-30.

Hayton, K., Thom, G., Percy, V., Boyd, C. and Latimer, K. (2008) Evaluation of the Scottish Co-Investment Fund. Scottish Enterprise, Glasgow

Hellmann, T. and Puri, M. (2000) The interaction between product market and financing strategy: the role of Venture Capital Review of Financial Studies, 13, 959-984

Hellman, T. and Puri, M. (2002) Venture capital and the professionalization of start-ups: Empirical Evidence Journal of Finance, 57, 169-197

HM Government (2009) New Industry, New Jobs. Department of Business, Enterprise and Regulatory Reform.

Hood, N. (2000) Public venture capital and economic development: the case of Scotland. Venture Capital: an international journal of entrepreneurial finance, 2, 313-341.

Langeland, O. (2007) Financing innovation: the role of Norwegian venture capitalists in financing knowledge-intensive enterprises. European Planning Studies, 15, 1143-1161. 
Leleux, B. and Surlemont, B. (2003) Public versus private venture capital: seeding or crowding out? A Pan-European analysis. Journal of Business Venturing, 18 (1) 81-104.

Lerner, J. (2009) Boulevard of Broken Dreams: Why Public Efforts to Boost Entrepreneurship and Venture Capital Have Failed--and What to Do About It. Princeton University Press, Princeton: NJ.

Lerner, J. and Watson, B. (2008) The public venture capital challenge: the Australian case. Venture Capital: an international journal of entrepreneurial finance, 10 (1) 1 - 20

Madill, J. J., G. H. Haines, jr. and A.L. Riding (2005) The role of angels in technology SMEs: a link to venture capital. Venture Capital: An International Journal of Entrepreneurial Finance, 7: 107-129.

Martin, R L (1989) The growth and geographical anatomy of venture capital in the United Kingdom, Regional Studies, 23, 389-403.

Martin, R. L. (1992) Financing regional enterprise: the role of the venture capital market, in R Townroe and R L Martin (eds) Regional Development in the 1990s: The British Isles in Transition. Jessica Kingsley: London, pp 161-171.

Martin, R., Sunley, P. and Turner, D. (2002) Taking risks in regions: the geographical anatomy of Europe's emerging venture capital market. Journal of Economic Geography, 2 (2), 121150.

Martin, R., C. Berndt, B. Klagge and P. Sunley (2005) Spatial proximity effects and regional equity gaps in the venture capital market: evidence from Germany and the UK. Environment and Planning A, 37, 1207-1231.

Mason, C. M. (1987) Venture capital in the United Kingdom: a geographical perspective. National Westminster Bank Quarterly Review, May, 47-59. 
Mason, C.M. (2006) Informal sources of venture finance, in S C Parker (ed) The Life Cycle of Entrepreneurial Ventures. New York: Springer, pp.259-299.

Mason, C. M. (2007) Venture capital: a geographical perspective, in H Landström (ed) Handbook of Research on Venture Capital. Edward Elgar, Cheltenham, pp 86-112.

Mason, C. M. and Harrison, R. T. (1991) Venture capital, the equity gap and the north-south divide in the UK, in M Green (ed.) Venture Capital: International Comparisons. Routledge, London, pp 202-247.

Mason, C. M. and R.T. Harrison (2002) The geography of venture capital investments in the UK. Transactions of the Institute of British Geographers, 27, 427-451.

Mason, C. M. and Harrison, R. T. (2003) Closing the regional equity gap? A critique of the Department of Trade and Industry's Regional Venture Capital Funds initiative. Regional Studies, 37, 855-868.

Mason, C. M. and Harrison, R. T. (2008) Measuring business angel investment activity in the United Kingdom: a review of potential data sources. Venture Capital: an international journal of entrepreneurial finance, 10, 309-330.

Mason, C. M. and Harrison, R. T. (2010) Annual Report on the Business Angel Market in the United Kingdom: 2008/9. Department for Business, Innovation and Skills. at http://www.bis.gov.uk/assets/biscore/enterprise/docs/a/10-994-annual-report-businessangel-market-2008-2009

Murray, G. C. (1998) A policy response to regional disparities in the supply of risk capital to new technology-based firms in the European Union. Regional Studies, 32, 405-419.

Murray, G. (1999) Seed capital funds and the effect of scale economies. Venture Capital: An International Journal of Entrepreneurial Finance, 1 (4) 351-384. 
Murray, G. C .(2007) Venture capital and government policy, in H Landström (ed) Handbook of Research on Venture Capital. Cheltenham: Edward Elgar, pp 113-151.

National Audit Office (2009) The Department for Business, Innovation and Skills: Venture Capital Support To Small Businesses. Report by the Comptroller and Auditor General. HC23 Session 2009-10. London: The Stationary Office.

Nightingale, P., Murray, G., Cowling, M., Baden-Fuller, C., Mason, C., Siepel, J., Hopkins, M. and Dannreuther, C. (2009) From Funding Gaps to Thin Markets: Designing Hybrid VC Schemes for the $21^{\text {st }}$ century. SPRU, University of Sussex for BVCA and NESTA.

Peneder, M. (2010) The impact of venture capital on innovation behaviour and firm growth. Venture Capital: An International Journal of Entrepreneurial Finance, 12 (2), 83 - 107

Pierrakis, Y. and Mason, C. (2008) Shifting Sands: The Changing Nature of the Early Stage Venture Capital Market in the UK. Research Report, NESTA, London.

Pierrakis, Y. and Westlake, S. (2009) Reshaping the UK Economy: the role of public investment in financing growth. Research Report 91, NESTA: London

Roseillo, A. and Parris, S. (2009) The patterns of venture capital investment in the UK biohealthcare sector: the role of proximity, cumulative learning and specialisation. Venture Capital: an international journal of entrepreneurial finance, 11 (3), 185-211.

Sahlman, W. A. and Stevenson, H. H. (1985) Capital Market Myopia. Journal of Business Venturing 1 (1), 7-30.

Schafer, D. and Schilder, D. (2009) Smart capital in German start-ups: an empirical analysis. Venture Capital: an international journal of entrepreneurial finance, 11 (2) 163-183. Schwartz, D. and Bar-El, R. (2007) Venture investments in Israel - a regional perspective. European Planning Studies, 15, 623-644. 
Sorenson, O. and T.E. Stuart (2001) Syndication networks and the spatial distribution of venture capital investments. American Journal of Sociology, 106 (6), 1546-1588.

SQW Consulting (2009) The Supply of Equity Finance to SMEs: Revisiting the 'Equity Gap'.

Department of Business, Enterprise and Regulatory Reform and Department for Innovation, University and Skills.

Sunley, P., Klagge, B., Berndt, C. and Martin, R. (2005) Venture capital programmes in the UK and Germany: in what sense regional policies? Regional Studies, 39 (2), 255-273.

Thompson, C. (1989) The geography of venture capital. Progress in Human Geography, 31 (1), $62-99$.

Valliere, D. and Peterson, R. (2004) Inflating the bubble: examining dot-com investor behaviour. Venture Capital: an international journal of entrepreneurial finance, 6 (1) 1-22.

Zhang, J. (2007) Access to venture capital and the performance of venture capital-backed starups in Silicon Valley. Economic Development Quarterly, 21, 124-147.

Zook, M.A. (2002) Grounded capital: venture financing and the geography of the Internet industry, 1994-2000. Journal of Economic Geography, 2 (2), 151-177. 
Table 1. Publicly backed venture capital funds

\begin{tabular}{|c|c|c|c|c|c|c|c|c|}
\hline Scheme name & details & Size of fund & $\begin{array}{l}\text { Government } \\
\text { commitment }\end{array}$ & $\begin{array}{l}\text { Contribution } \\
\text { (percentage) } \\
\text { from other } \\
\text { investors }\end{array}$ & $\begin{array}{l}\text { Year } \\
\text { commenced }\end{array}$ & $\begin{array}{l}\text { End of } \\
\text { investment } \\
\text { period }\end{array}$ & $\begin{array}{l}\text { Upper } \\
\text { investment } \\
\text { limit }\end{array}$ & $\begin{array}{l}\text { Geographical } \\
\text { focus }\end{array}$ \\
\hline $\begin{array}{l}\text { Regional Venture } \\
\text { Capital Funds } \\
\text { (RVCFs) }\end{array}$ & $\begin{array}{l}\text { Hybrid funds in each } \\
\text { RDA (nine funds in } \\
\text { total) }\end{array}$ & $\begin{array}{l}\text { Range from } \\
£ 12 \mathrm{~m}-£ 46 \mathrm{~m} \\
\text { (total } \\
£ 226.5 \mathrm{~m} \text { ) }\end{array}$ & $£ 74.4 \mathrm{~m}$ & $\begin{array}{l}£ 512.1 \mathrm{~m} \\
(67.2 \%)\end{array}$ & $2002-2003$ & $2007-2008$ & $\begin{array}{l}£ 500,000 \\
(£ 660,000)\end{array}$ & regional \\
\hline $\begin{array}{l}\text { UK High Technology } \\
\text { Fund }\end{array}$ & A fund-of-funds & $£ 126.1 \mathrm{~m}$ & $£ 20 \mathrm{~m}$ & $\begin{array}{l}£ 106,1 \mathrm{~m} \\
(84.1 \%)\end{array}$ & $2000-2002$ & 2006 & No limit & national \\
\hline Early Growth Funds & $\begin{array}{l}\text { Six free-standing } \\
\text { funds }\end{array}$ & $\begin{array}{l}\text { Range from } \\
£ 3 \mathrm{~m} \text { to } £ 5 \mathrm{~m} \\
\text { (total } £ 91 \mathrm{~m} \text { ) }\end{array}$ & $£ 26.5 \mathrm{~m}$ & $\begin{array}{l}£ 70.9 \mathrm{~m} \\
(70.9 \%)\end{array}$ & $2002-2004$ & 2014-2016 & $£ 100,000$ & regional \\
\hline
\end{tabular}

Source: National Audit Office (2009) 
TABLE 2 UK early stage investments 2001-2008

(a) Amount invested (£m)

\begin{tabular}{|c|c|c|c|c|c|c|c|c|c|}
\hline $\begin{array}{l}\text { Finance } \\
\text { stage }\end{array}$ & 2000 & 2001 & 2002 & 2003 & 2004 & 2005 & 2006 & 2007 & 2008 \\
\hline Start-up & 175 & 163 & 99 & 73 & 96 & 160 & 531 & 190 & 172 \\
\hline $\begin{array}{l}\text { Other } \\
\text { early stage }\end{array}$ & 528 & 227 & 196 & 190 & 188 & 222 & 415 & 244 & 187 \\
\hline $\begin{array}{l}\text { Total early } \\
\text { stage }\end{array}$ & 703 & 390 & 295 & 263 & 284 & 382 & 946 & 434 & 359 \\
\hline $\begin{array}{l}\text { Early } \\
\text { stage as a } \\
\% \text { of total } \\
\text { investment }\end{array}$ & 11.0 & 8.2 & 6.6 & 6.5 & 4.2 & 5.6 & 9.3 & 3.6 & 4.1 \\
\hline
\end{tabular}

(b) Number of investments

\begin{tabular}{lrrrrrrrrr}
\hline Finance stage & 2000 & 2001 & 2002 & 2003 & 2004 & 2005 & 2006 & 2007 & 2008 \\
\hline Start-up & 153 & 190 & 165 & 185 & 190 & 208 & 245 & 207 & 170 \\
Other early stage & 256 & 218 & 233 & 242 & 264 & 285 & 255 & 295 & 285 \\
Total early stage & 409 & 408 & 398 & 427 & 454 & 493 & 500 & 502 & 455 \\
Early stage as a \% of & & & & & & & & & \\
total investment & 35 & 31 & 33 & 34 & 35 & 38 & 38 & 38 & 36 \\
\hline
\end{tabular}

(c) Average size of early stage investments

\begin{tabular}{cccccccccc}
\hline year & 2000 & 2001 & 2002 & 2003 & $\begin{array}{l}2004 \\
£ 000\end{array}$ & 2005 & 2006 & 2007 & 2008 \\
\hline $\begin{array}{c}\text { Average } \\
\text { size of } \\
\text { investment }\end{array}$ & 1,719 & 956 & 741 & 616 & 626 & 775 & 1,892 & 865 & 789 \\
\hline
\end{tabular}

Source: BVCA Report on Investment Activity (various years) 
TABLE 3. Distribution of early stage investments in the UK: number and region

\begin{tabular}{|c|c|c|c|c|c|c|c|c|c|c|c|c|}
\hline \multirow[t]{2}{*}{ region } & \multicolumn{3}{|c|}{$\begin{array}{c}1998-2000 \\
\text { ('boom years') }\end{array}$} & \multicolumn{3}{|c|}{$\begin{array}{c}2001-3 \\
\text { ('crash years') }\end{array}$} & \multicolumn{3}{|c|}{$\begin{array}{c}2005-7 \\
\text { ('recovery years') }\end{array}$} & \multicolumn{3}{|c|}{$\begin{array}{c}2008 \\
\text { ('financial crisis') }\end{array}$} \\
\hline & No. & $\%$ & LQ* & No. & $\%$ & LQ & no. & $\%$ & LQ & No. & $\%$ & LQ \\
\hline London & 252 & 27.70 & 1.86 & 217 & 17.60 & 1.14 & 289 & 19.36 & 1.15 & 78 & 17.14 & 1.08 \\
\hline $\begin{array}{l}\text { South } \\
\text { East }\end{array}$ & 190 & 20.90 & 1.36 & 233 & 18.90 & 1.20 & 282 & 18.89 & 1.18 & 74 & 16.26 & 1.03 \\
\hline $\begin{array}{l}\text { South } \\
\text { West }\end{array}$ & 36 & 3.96 & 0.41 & 56 & 4.54 & 0.48 & 106 & 7.10 & 0.79 & 25 & 5.49 & 0.58 \\
\hline $\begin{array}{l}\text { East of } \\
\text { England }\end{array}$ & 107 & 11.76 & 1.17 & 205 & 16.63 & 1.66 & 161 & 10.78 & 1.06 & 29 & 6.37 & 0.63 \\
\hline $\begin{array}{l}\text { West } \\
\text { Midlands }\end{array}$ & 39 & 4.29 & 0.51 & 57 & 4.62 & 0.56 & 92 & 6.10 & 0.73 & 45 & 2.42 & 0.35 \\
\hline $\begin{array}{l}\text { East } \\
\text { Midlands }\end{array}$ & 28 & 3.08 & 0.45 & 31 & 2.51 & 0.37 & 60 & 4.02 & 0.59 & 11 & 9.89 & 1.20 \\
\hline $\begin{array}{l}\text { Yorkshire } \\
\& \text { The } \\
\text { Humber }\end{array}$ & 37 & 4.07 & 0.55 & 44 & 3.57 & 0.50 & 49 & 3.29 & 0.46 & 28 & 6.15 & 0.86 \\
\hline $\begin{array}{l}\text { North } \\
\text { West }\end{array}$ & 56 & 6.15 & 0.63 & 117 & 9.49 & 1.00 & 212 & 14.20 & 1.40 & 79 & 17.36 & 1.81 \\
\hline $\begin{array}{l}\text { North } \\
\text { East }\end{array}$ & 22 & 2.42 & 0.95 & 40 & 3.24 & 1.29 & 45 & 3.01 & 1.11 & 22 & 4.84 & 1.88 \\
\hline Scotland & 106 & 11.65 & 1.59 & 101 & 8.19 & 1.15 & 110 & 7.37 & 1.17 & 33 & 2.86 & 0.67 \\
\hline Wales & 15 & 1.65 & 0.35 & 57 & 4.62 & 1.28 & 50 & 3.35 & 0.85 & 13 & 7.25 & 1.04 \\
\hline $\mathrm{N}$ Ireland & 22 & 2.42 & 0.72 & 75 & 6.08 & 1.83 & 38 & 2.54 & 1.01 & 18 & 3.96 & 1.21 \\
\hline
\end{tabular}

Source: calculated from BVCA Report on Investment Activity (various years) 
TABLE 4. Distribution of early stage investments in the UK: amount invested and region

\begin{tabular}{|c|c|c|c|c|c|c|c|c|c|c|c|c|}
\hline \multirow[t]{2}{*}{ region } & \multicolumn{3}{|c|}{$\begin{array}{c}1998-2000 \\
\text { ('boom years') }\end{array}$} & \multicolumn{3}{|c|}{$\begin{array}{c}2001-3 \\
\text { ('crash years') }\end{array}$} & \multicolumn{3}{|c|}{$\begin{array}{c}2005-7 \\
\text { ('recovery years') }\end{array}$} & \multicolumn{3}{|c|}{$\begin{array}{c}2008 \\
\text { ('financial crisis') }\end{array}$} \\
\hline & $£ \mathrm{~m}$ & $\%$ & LQ* & $£ \mathrm{~m}$ & $\%$ & $\begin{array}{l}\text { LQ } \\
\end{array}$ & $£ \mathrm{~m}$ & $\%$ & $\begin{array}{l}\text { LQ } \\
\end{array}$ & $£ \mathrm{~m}$ & $\%$ & $\begin{array}{l}\mathrm{LQ} \\
\end{array}$ \\
\hline London & 329 & 22.0 & 1.43 & 229 & 24.9 & 1.56 & 524 & 29.74 & 1.76 & 172 & 47.8 & 3.02 \\
\hline South East & 522 & 34.9 & 2.10 & 238 & 25.8 & 1.64 & 353 & 20.03 & 1.25 & 64 & 17.8 & 1.13 \\
\hline South West & 67 & 4.5 & 0.50 & 26 & 3.9 & 0.42 & 144 & 8.17 & 0.91 & 12 & 3.3 & 0.35 \\
\hline $\begin{array}{l}\text { East of } \\
\text { England }\end{array}$ & 111 & 7.4 & 0.76 & 216 & 23.5 & 2.32 & 228 & 12.94 & 1.28 & 20 & 5.6 & 0.55 \\
\hline $\begin{array}{l}\text { West } \\
\text { Midlands }\end{array}$ & 62 & 4.1 & 0.50 & 17 & 1.8 & 0.22 & 28 & 1.59 & 0.19 & 12 & 3.3 & 0.41 \\
\hline $\begin{array}{l}\text { East } \\
\text { Midlands }\end{array}$ & 45 & 3.0 & 0.44 & 22 & 2.4 & 0.35 & 144 & 8.17 & 1.20 & 9 & 2.5 & 0.36 \\
\hline $\begin{array}{l}\text { Yorkshire } \\
\& \text { The } \\
\text { Humber }\end{array}$ & 76 & 5.1 & 0.72 & 10 & 1.1 & 0.16 & 137 & 7.76 & 1.07 & 5 & 1.4 & 0.19 \\
\hline North West & 103 & 6.9 & 0.76 & 54 & 5.9 & 0.61 & 99 & 5.62 & 0.56 & 23 & 6.4 & 0.67 \\
\hline North East & 15 & 1.0 & 0.40 & 6 & 0.7 & 0.26 & 16 & 0.91 & 0.34 & 10 & 2.8 & 1.08 \\
\hline Scotland & 129 & 8.6 & 1.19 & 64 & 6.9 & 0.99 & 49 & 2.78 & 0.44 & 24 & 6.7 & 0.13 \\
\hline Wales & 14 & 0.9 & 0.20 & 31 & 3.4 & 0.78 & 29 & 1.65 & 0.42 & 2 & 0.6 & 0.95 \\
\hline $\mathrm{N}$ Ireland & 24 & 1.6 & 0.48 & 25 & 2.7 & 0.85 & 11 & 0.62 & 0.25 & 7 & 1.9 & 0.60 \\
\hline TOTAL & 1497 & & & 921 & & to & 1762 & & & 360 & & \\
\hline
\end{tabular}

Source: calculated from BVCA Report on Investment Activity (various years) 
Figure 1

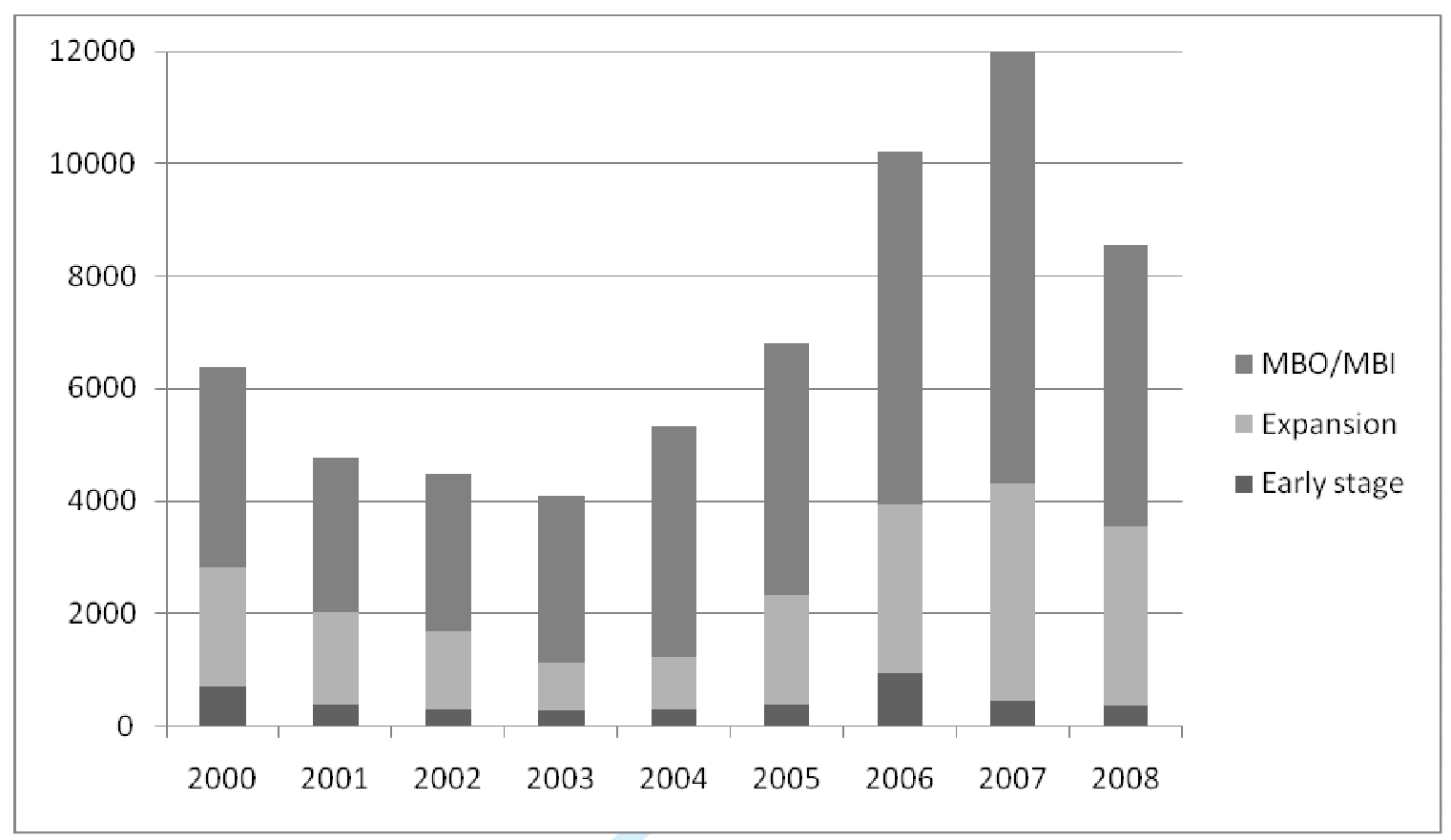

1

2

3

4

5

6

10

11

12

13

14

15

16

17

18

19

20

21

22

23

24

25

26

27

28

29

30

31

32

33

34

35

36

37

38

39

40

41

42

43

44

45

46

47

48

49

50

51

52

53

54

55

56

57

58

59

60

http://mc.manuscriptcentral.com/cres Email: regional.studies@fm.ru.nl 
Figure 2

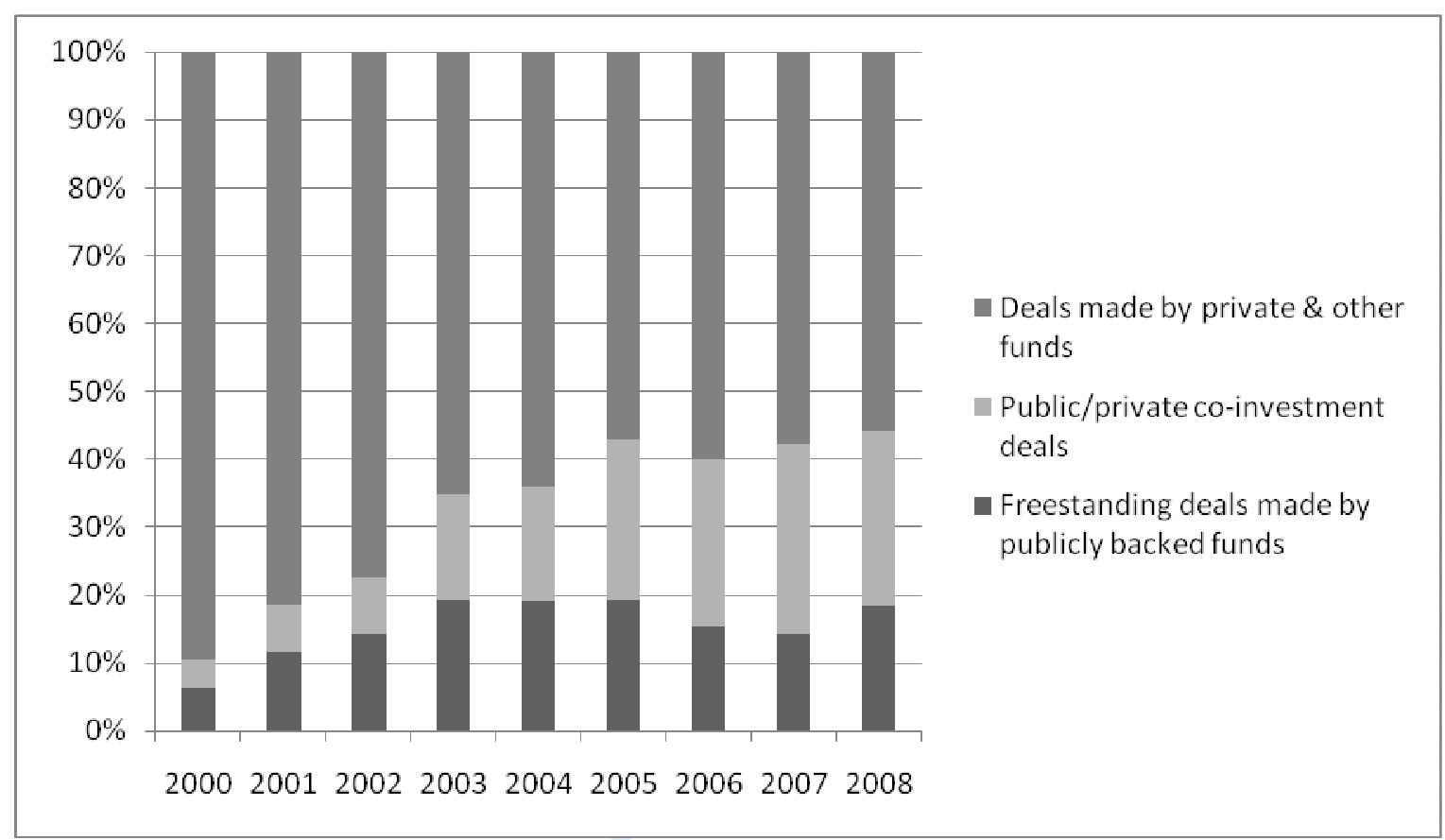

http://mc.manuscriptcentral.com/cres Email: regional.studies@fm.ru.nl 
Figure 3: Co-investments as a proportion of deals

(a) Public private co-investments deals as a proportion of all deals involving public sector

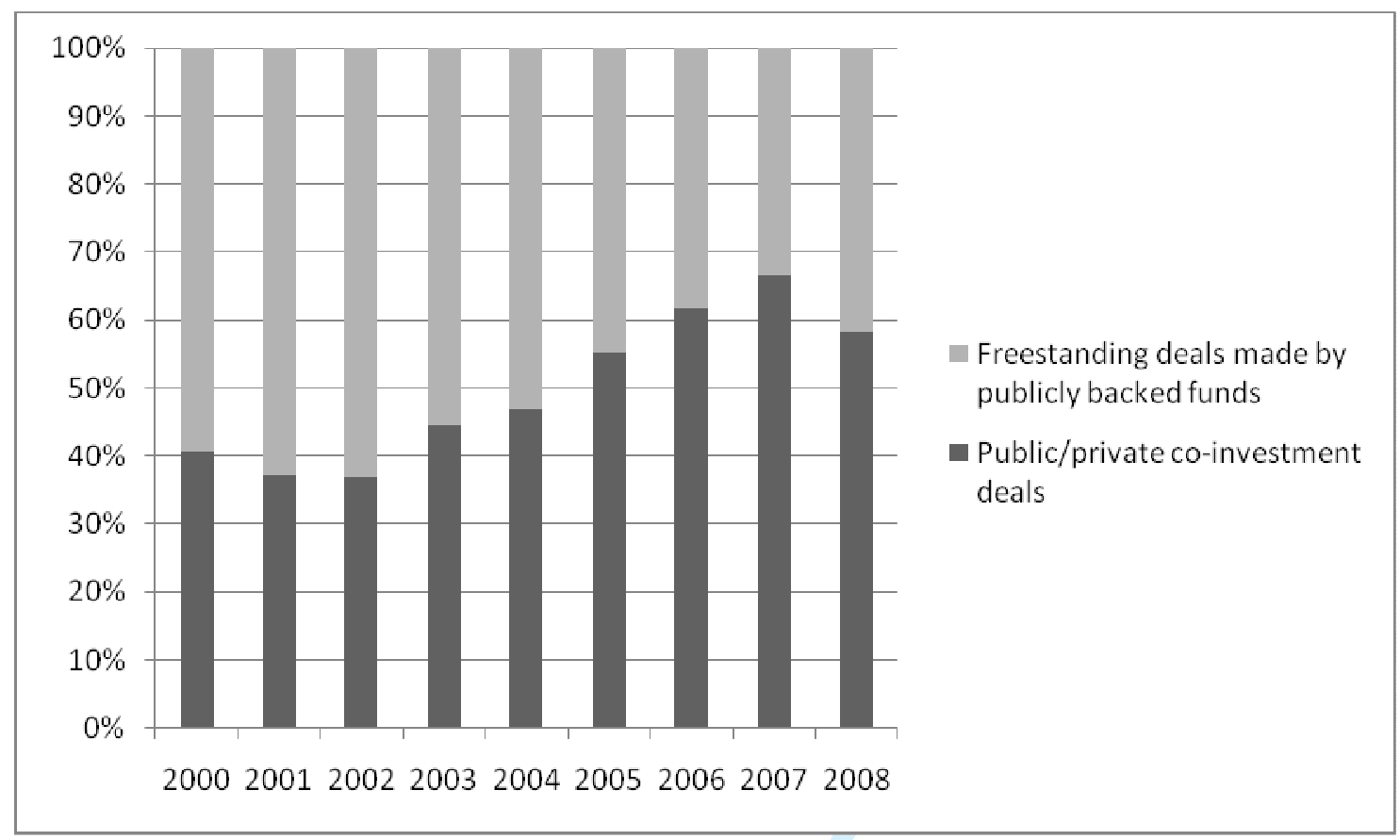

(b) Public private co-investments deals as a proportion of all deals involving private sector 


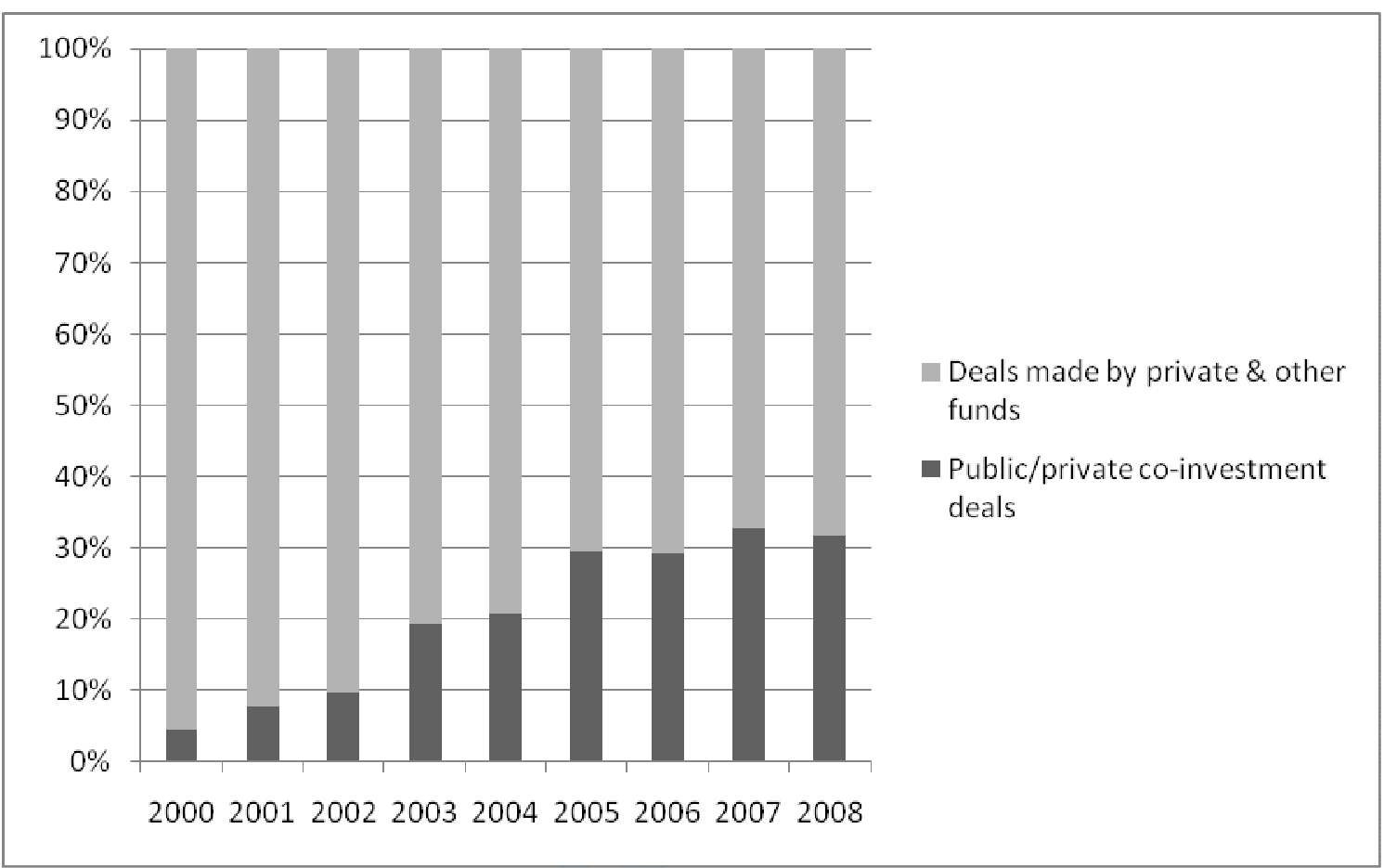

Figure 4

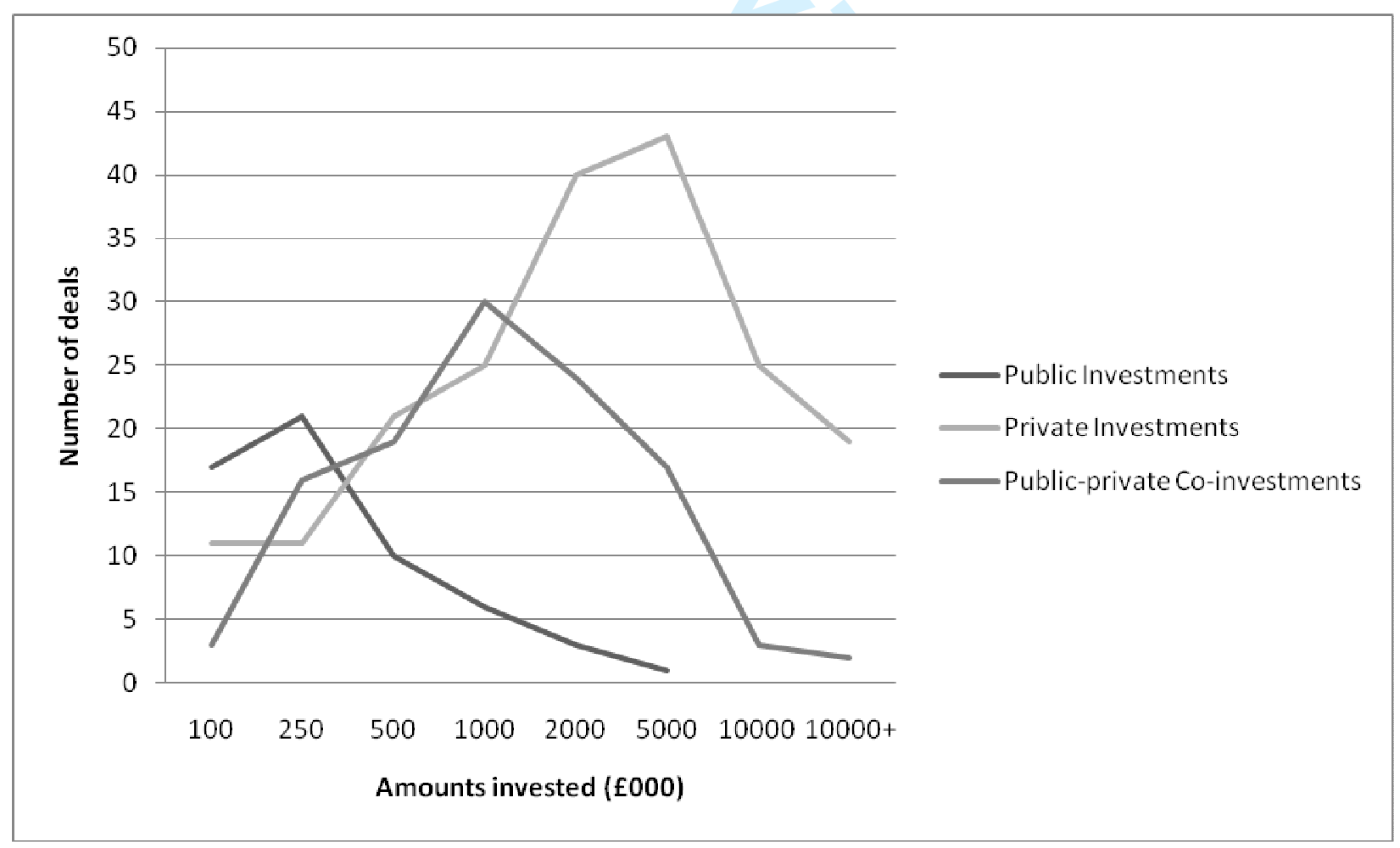

http://mc.manuscriptcentral.com/cres Email: regional.studies@fm.ru.nl 
Figure 5

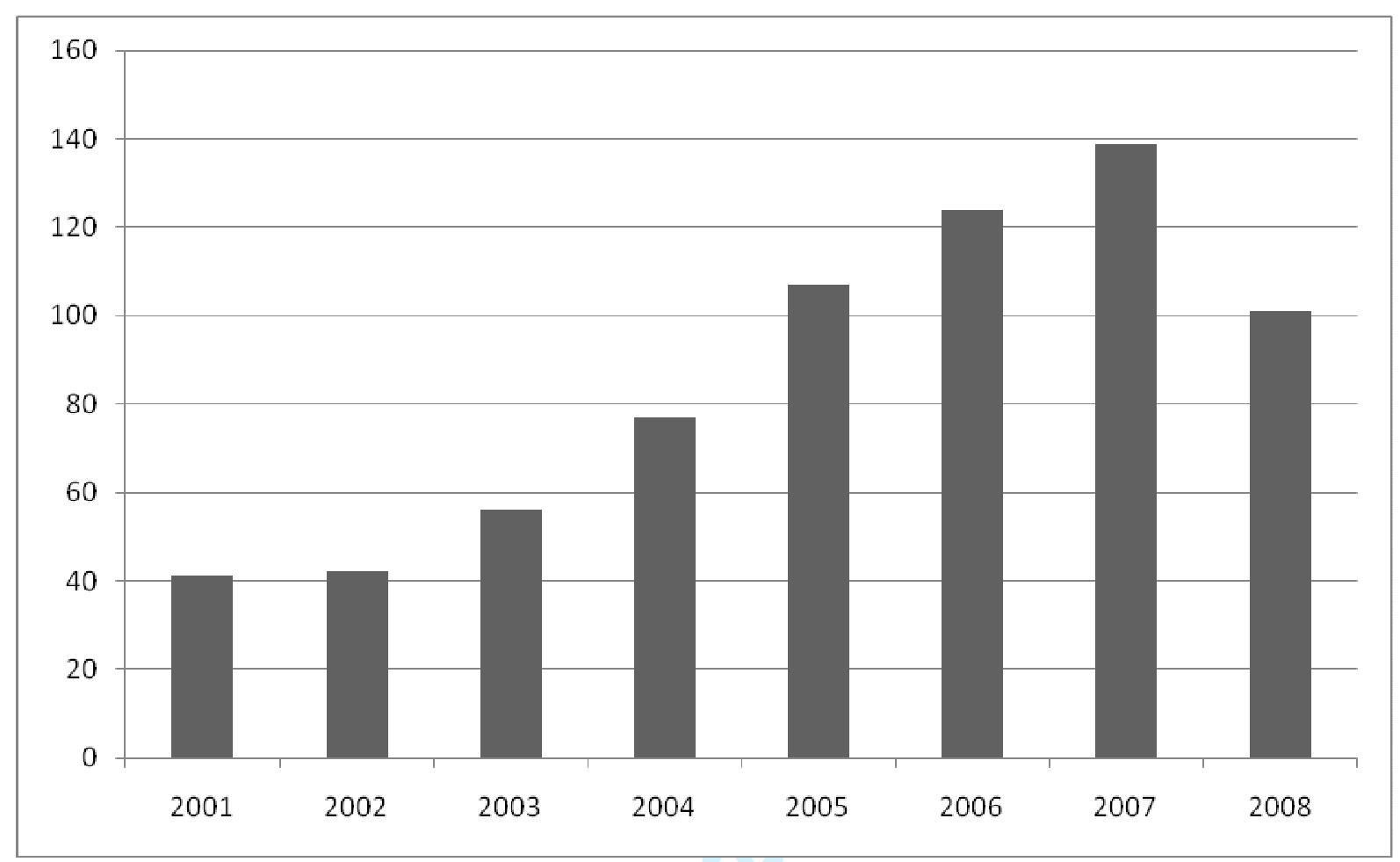

1

2

3

4

5

6

10

11

12

13

14

15

16

17

18

19

20

21

22

23

24

25

26

27

28

29

30

31

32

33

34

35

36

37

38

39

40

41

42

43

44

45

46

47

48

49

50

51

52

53

54

55

56

57

58

59

60

http://mc.manuscriptcentral.com/cres Email: regional.studies@fm.ru.nl 
Figure 6

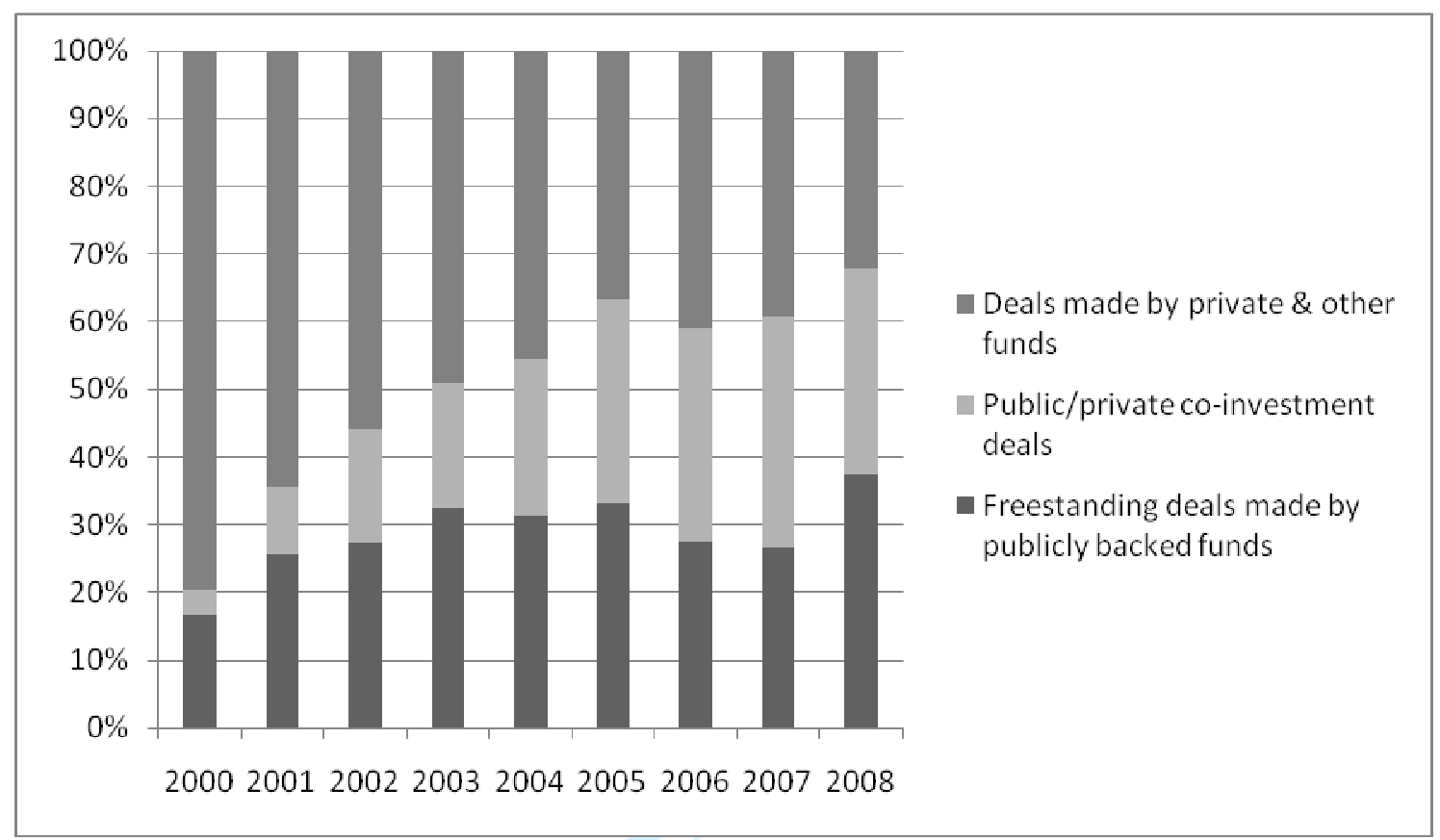


Figure 7

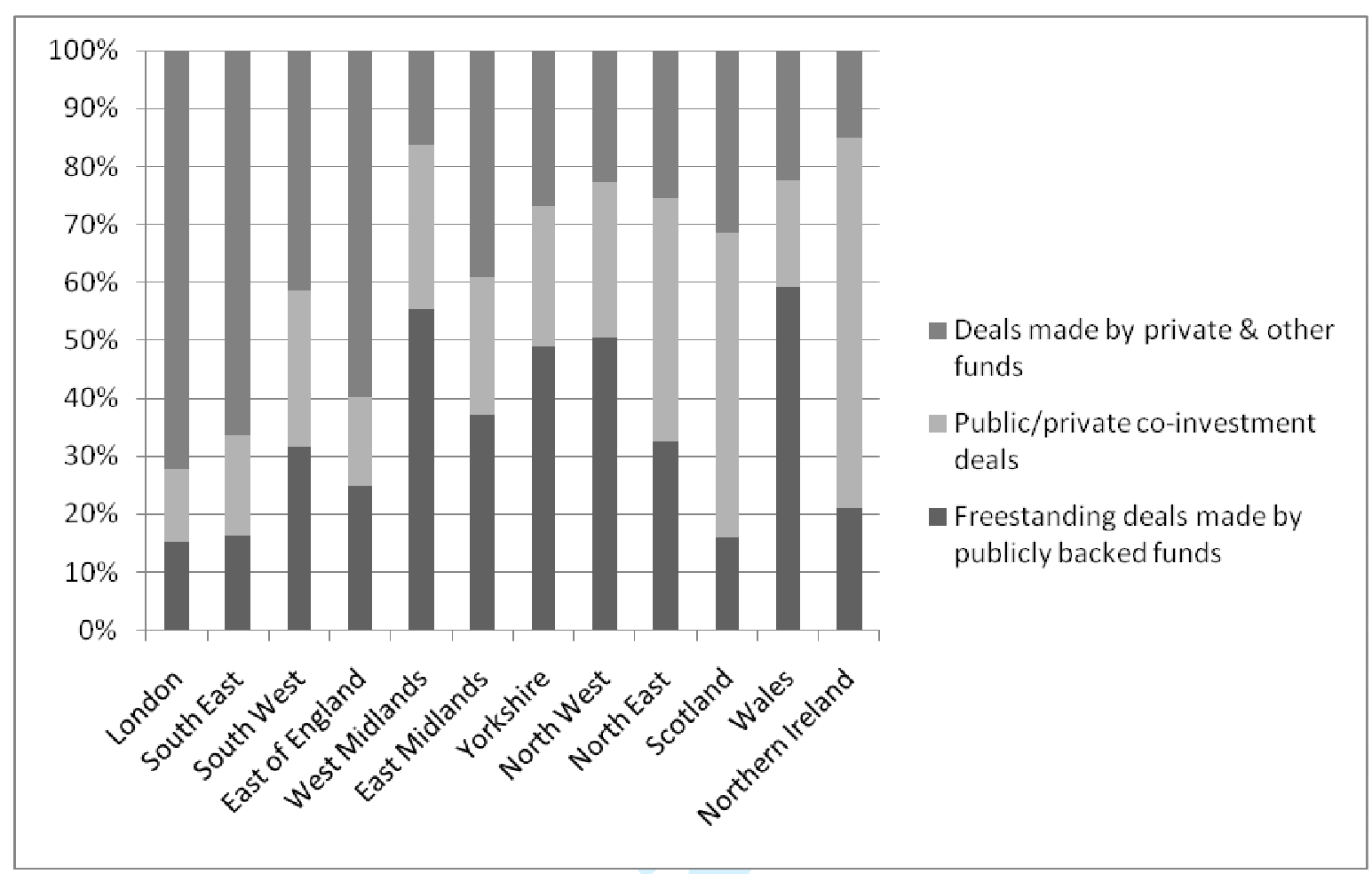

Figures 8 and 9 in separate files. 


\section{NOTES}

${ }^{1}$ We make an important distinction between venture capital and private equity. Venture capital focuses on investing in new businesses whereas private equity focuses on restructuring, management (leveraged) buyouts and other forms of ownership change in established companies.

${ }^{2}$ See Mason and Harrison (2003) for an early critique of the scheme.

${ }^{3}$ See www.onenortheast.co.uk/page/jeremie/ index.cfm for details of the funds to be established in the North

East.

${ }^{4}$ This source was also used by Pierrakis and Mason (2008). Some of the figures reported here may differ slightly from those cited by Pierrakis and Mason (2008): (i) the Library House database is live and so is continually being updated; (ii) further cleaning of the data by the authors. However, these changes do not change the observed trends and the argument made by Pierrakis and Mason (2008).

${ }^{5}$ Investments of $£ 50,000$ or more reported by Library House as a proportion of those in the BVCA statistics have risen from $33 \%$ in 2000 to over $50 \%$ since 2005

${ }^{6}$ However, there is no source which provides a comprehensive coverage of angel investments (Mason and Harrison, 2008)

${ }^{7}$ Unfortunately the data does not enable us to differentiate between investments made by public sector coinvestment funds and ad hoc co-investments made by other types of public sector venture capital funds.

${ }^{8}$ Yorkshire's location quotient was 0.49 in 2005, 1.62 in 2006 and 0.38 in 2007. East Midland's location quotient was 2.41 in 2005, 0.57 in 2006 and 0.64 in 2007.

${ }^{9}$ The pooled interim rate of return across the nine funds that were recipients of the UK High Technology Funds in June 2008 was minus $9.7 \%$ (net of fund management costs), with only one of the funds showing a positive rate of return. Comparable private technology funds show a pooled average return of minus $5.2 \%$ at that date. The pooled rate of return across the nine finds at December 2008 was minus 15.7\%, with all funds showing negative returns. 
Private funds of a similar size and vintage show a minus $0.4 \%$ return. However, these funds are subject to fewer investment restrictions (NAO, 2009). 


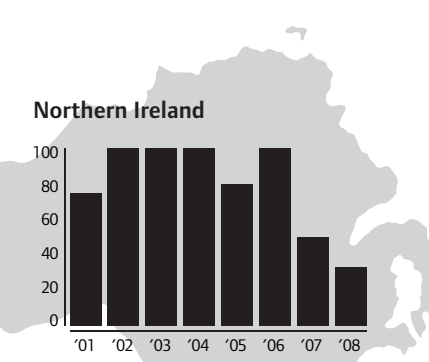

Scotland

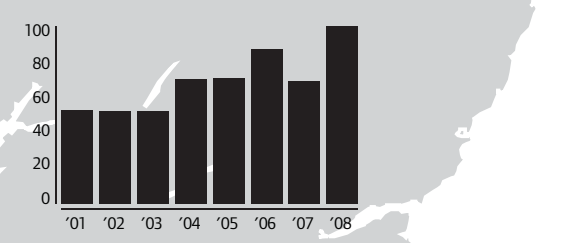

North East
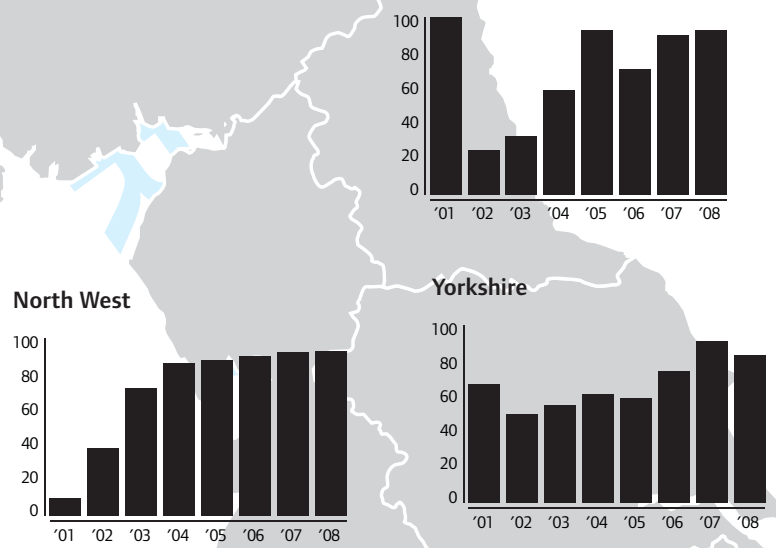

41
43
43
4
45
6
7
48
9
50
5
5
53
54
55
56
57
58
59

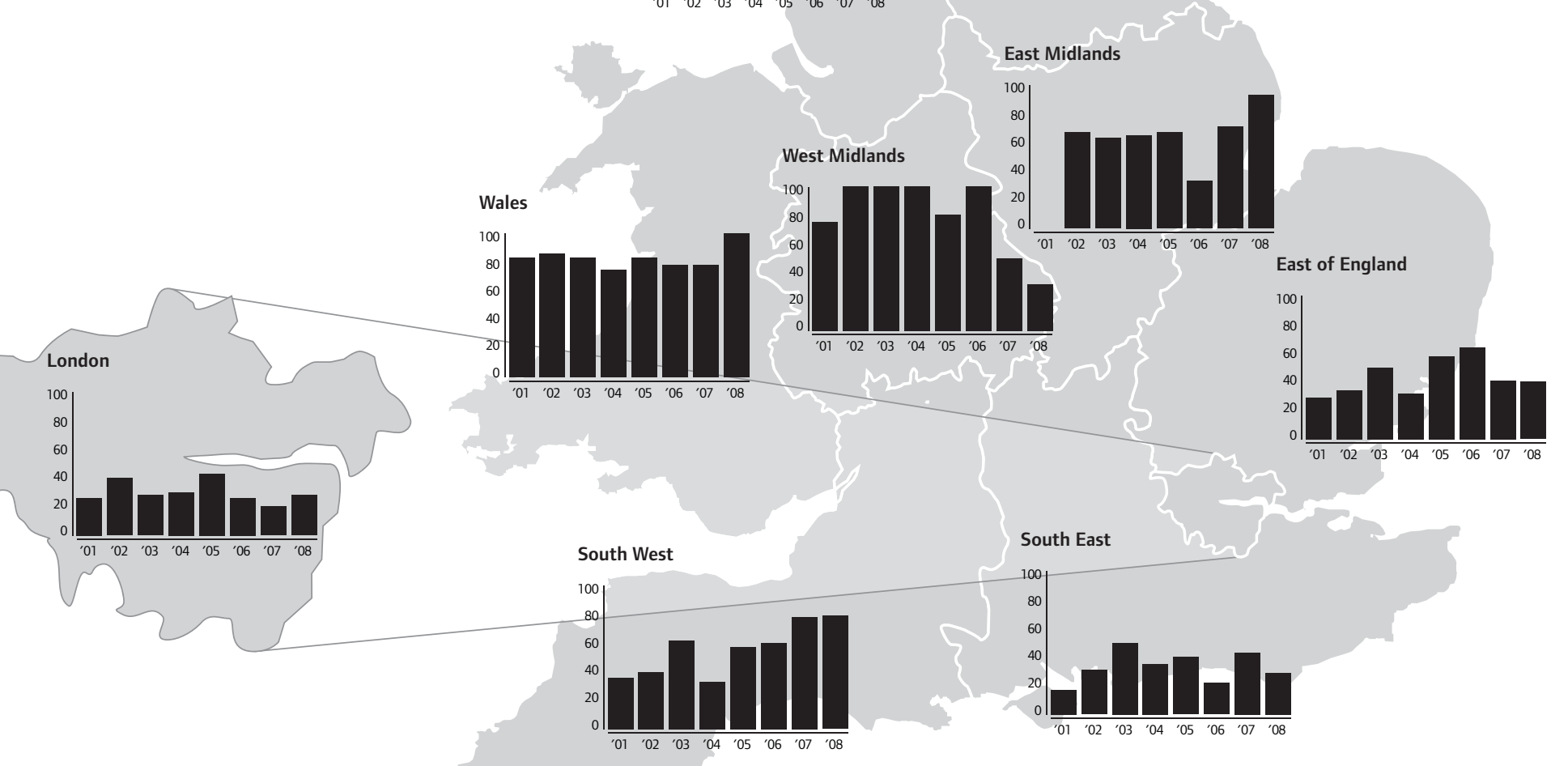




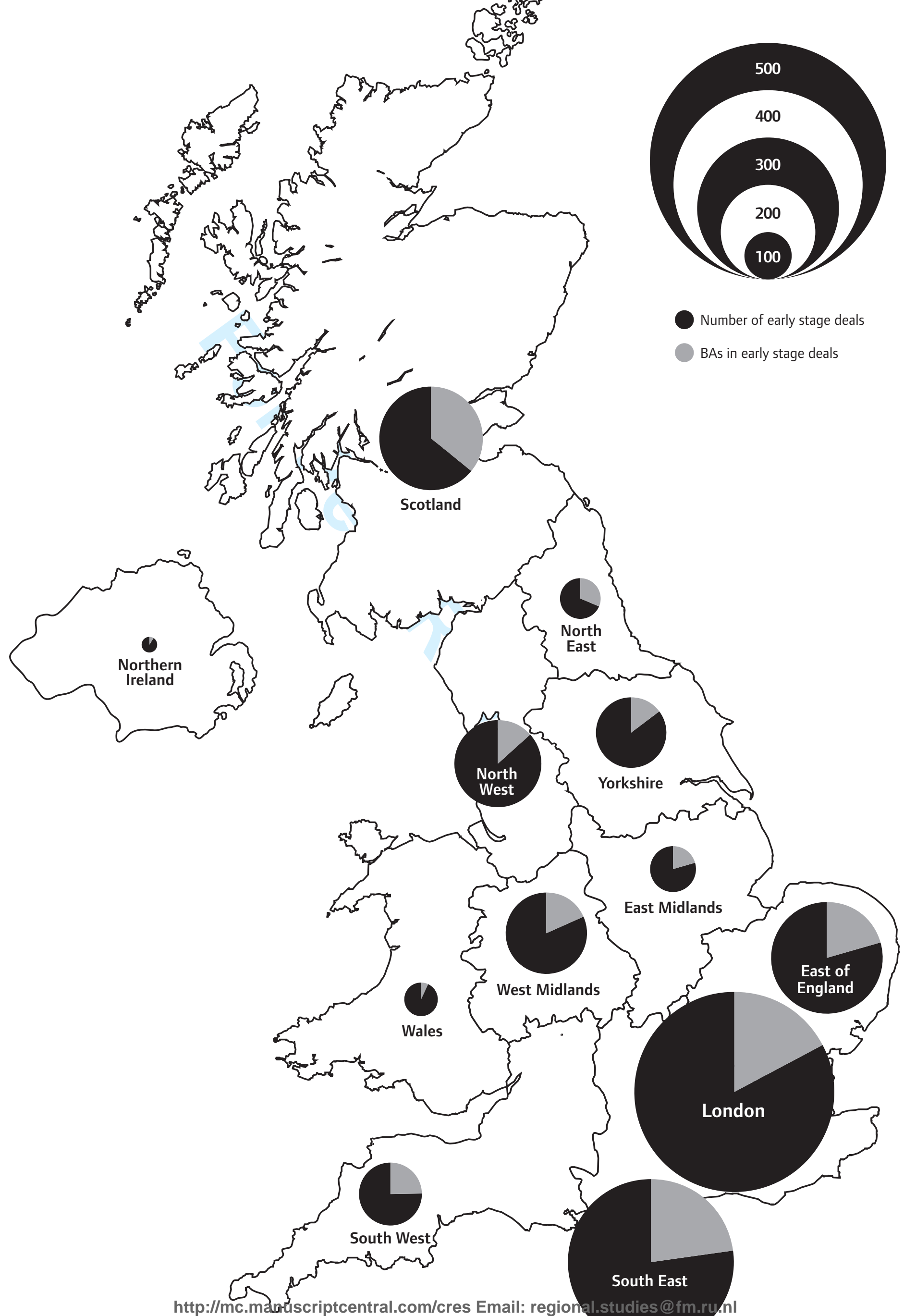

